\title{
GENE EXPRESSION CHANGES AND ANTI-PROLIFERATIVE EFFECT OF NONI (Morinda citrifolia) FRUIT EXTRACT ANALYSED BY REAL TIME-PCR
}

\section{PERUBAHAN EKSPRESI GEN DAN EFEK ANTI-PROLIFERASI EKSTRAK BUAH NONI (Morinda citrifolia) DIANALISIS DENGAN REAL TIME-PCR}

\author{
Hermansyah $^{1 *}$, Susilawati \\ ${ }^{1}$ Department of Chemistry, Faculty of Mathematics and Natural Sciences, \\ Sriwijaya University, Palembang, Indonesia \\ ${ }^{2}$ Faculty of Medicine, Sriwijaya University, Palembang, Indonesia \\ *email : hermansyah@unsri.ac.id
}

Received March 15, 2017; Accepted May 10, 2017; Available online May 30, 2017

\begin{abstract}
To elucidate the anti-proliferative effect of noni (Morinda citrifolia) fruit extract for a Saccharomyces cerevisiae model organism, analysis of gene expression changes related to cell cycle associated with inhibition effect of noni fruit extract was carried out. Anti-proliferative of noni fruit extract was analyzed using gene expression changes of Saccharomyces cerevisiae (strains FY833 and BY4741). Transcriptional analysis of genes that play a role in cell cycle was conducted by growing cells on YPDAde broth medium containing $1 \%$ (w/v) noni fruit extract, and then subjected using quantitative real-time polymerase chain reaction (RT-PCR). Transcriptional level of genes CDC6 (Cell Division Cycle-6), CDC20 (Cell Division Cycle-20), FAR1 (Factor ARrest-1), FUS3 (FUSsion-3), SIC1 (Substrate/Subunit Inhibitor of Cyclin-dependent protein kinase-1), WHI5 (WHIskey-5), YOXI (Yeast homeobOX-1) and YHPI (Yeast Homeo-Protein-1) increased, oppositely genes expression of DBF4 (DumbBell Forming), MCM1 (Mini Chromosome Maintenance-1) and TAH11 (Topo-A Hypersensitive11) decreased, while the expression level of genes $C D C 7$ (Cell Division Cycle-7), MBP1 (MIul-box Binding Protein-1) and SWI6 (SWItching deficient-6) relatively unchanged. These results indicated that gene expression changes might associate with anti-proliferative effect from noni fruit extract. These gene expressions changes lead to the growth inhibition of S.cerevisiae cell because of cell cycle defect.
\end{abstract}

Keywords : Morinda citrifolia, Noni fruit, Saccharomyces cerevisiae, anti-proliferative

\begin{abstract}
ABSTRAK
Elusidasi efek anti-proliferasi buah mengkudu (Morinda citrifolia) pada organisme model Sacharomyces cerevisiae, melalui analisis perubahan ekspresi gen-gen berkaitan dengan siklus sel yang berasosiasi dengan efek inhibisi ekstrak buah noni. Anti-proliferasi ekstrak buah noni dianalisis menggunakan perubahan ekspresi gen Saccharomyces cerevisiae (galur FY833 dan BY4741). Analisis transkripsi gen-gen yang berperan dalam siklus sel dilakukan dengan menumbuhkan sel pada medium cair YPDAde mengandung $1 \%$ (b/v) ekstrak buah mengkudu, kemudian dianalisis menggunakan quantitative real time polymerase chain reaction (RT-PCR). Level transkripsi gen-gen CDC6 (Cell Division Cycle-6), CDC20 (Cell Division Cycle-20), FARI (Factor ARrest-1), FUS3 (FUSsion-3), SIC1 (Substrate/Subunit Inhibitor of Cyclin-dependent protein kinase-1), WHI5 (WHIskey-5), YOXI (Yeast homeobOX-1) dan YHPI (Yeast Homeo-Protein-1) meningkat, berbeda untuk ekspresi gen-gen DBF4 (DumbBell Forming-4), MCM1 (Mini Chromosome Maintenance-1) dan TAH11 (TopoA Hypersensitive-11) mengalami penurunan, sedangkan level ekspresi gen-gen CDC7 (Cell Division Cycle-7), MBP1 (MIul-box Binding Protein-1) and SWI6 (SWItching deficient-6) relatif tidak berubah. Hasil ini mengindikasikan bahwa perubahan ekspresi gen berasosiasi dengan efek anti-proliferasi ekstrak buah noni. Perubahan ekspresi gen tersebut menuju hambatan pertumbuhan sel S.cerevisiae karena kerusakan siklus selnya.
\end{abstract}

Kata kunci: Morinda citrifolia, Buah Mengkudu, Saccharomyces cerevisiae, dan anti-proliferasi.

\section{INTRODUCTION}

Morinda citrifolia L. (Noni plant), a unique horticultural plant belonging to Rubiaceae is a native plant from Southeast Asia to Australia and also spread in Polynesia, India, Central and Northern South America (Chan-Blanco, Vaillant, Perez, \& Brat, 2006). In Indonesia, it is known as mengkudu. However, it has many various local names such as kudu, pace, cengkudu, kemudu (Jawa); bengkudu, mengkudu, eodu (Sumatera); wangkudu, manakudu (Nusa tenggara), mangkudu, wangkudu, labanan (Kalimantan). This plant species is now cultivated throughout many tropical areas and various cultures throughout the world. 
Some chemical compounds were explored from M.citrofolia plants such as fatty acids and alcohol glycosides and numerous iridoid were reported from its fruit (Potterat and Hamburger, 2007). A new iridoid glycoside, citrifoside and new anthraquinone, 1,5,15-tri-O-methylmorindol, together with 24 known compounds were isolated from leaves of M.citrifolia (Takashima et al., 2007). Three new glycosides were also isolated from the fruits of Noni (Wang et al., 2002). An immunomodulatory polysaccharide-rich substance from the fruit juice was also discovered as an antitumor potential (Furusawa, Hirazumi, Story, \& Jensen, 2003). A new anthraquinone, 1,5,15-tri- $O$ methylmorindol and two new saccharide fatty acid esters have been isolated as a potential cancer chemopreventive constituents (Akihisa et al., 2007). Many others secondary metabolites have been isolated from this $M$. citrifolia.

As a folk medicine, noni plant is a reputed medicinal plant used to treat a wide variety of disease in Polynesia, south-east Asia, Australia, and Caribian (Takashima et al., 2007). Almost all part of noni plants such as roots, stems, barks, leaves, and fruits have been used folk medicine in many countries including in Indonesia. Moreover, it has been reported that noni fruit has a broad range therapeutic as the traditional folk medicine plants in some countries included Indonesia. Almost all of noni plant parts such as roots, stems, bark, leaves, flower, and fruit could be used in herbal remedies for cancer, infection, arthritis, diabetes, asthma, hypertension, and pain (Wang et al., 2002). Although the plant has also wide range of uses as a treatment for dysentery, heartburn liver disease, arthritis, diabetes, high blood pressure, muscle aches, menstrual difficulties, headaches, heart disease, AIDS, cancers, gastric ulcers, sprains, mental depression, senility, poor digestion, atherosclerosis, blood vessel problems, and drug addiction (Siddiqui, Sattar, Ahmad, \& Begum, et al, 2007). However, most of the mechanism for these effects remains unknown.

The budding yeast Saccharomyces cereviciae a model organism since it offers many advantages such as it can easily be manipulated. Due to its simple growth requirements and genetic tractability, this organism is a powerful tool for investigating the molecular regulation of cell cycle control
(Calvert and Lannigen, 2010). In the cell cycle progression of S.cerevisiae, bud emergence is a standard marker for entry into S-phase and thus defines the G1/S transition, while in large budded cells, nuclear migration and spindle formation are markers for the G2/M transition, whereas completion of anaphase can be determined by the presence of divided nuclei (Calvert, Lanniga, \& Pemberton, 2008). In this research, the budding yeast S.cerevisiae was used as a model organism to identify and explore the anti-proliferative or anticancer mechanism. We found that methanol extract of noni fruit could inhibit proliferative of $S$. cerevisiae especially in the G1/S phase of cell cycle progression (Hermansyah, Sugiyama, Kaneko \& Harashima, 2009) and this data indicated that noni fruit extract has anti-proliferative effect for organisms. By using real time Polymerase Chain Reaction (PCR), expression level of some genes involved in G1/S transition was checked in this experiment.

\section{MATERIALS AND METHODS}

\section{Yeast Strains and Culture Conditions}

Strains used in this study were yeast S.cerevisiae strains FY833 and BY4741 with genotype MATa ura3-52 his3- $\Delta 200$ leu2 $\Delta 1$ lys $2 \Delta 202 \operatorname{trp} 1 \Delta 63$ and MATa his3 31 leu2 $\Delta 0$ lys $2 \Delta 0$ ura3 $\Delta 0$. respectively (NBRP, YGRC or National BioResource Project/Yeast Genetic Research Center, Japan (http://yeast.lab.nig. ac.jp/nig/index_en.html) (Winston, Dollard, \& Ricupero-Hovasse, 1995). YPDAde media was prepared YPD broth (Sigma-Aldrich Co.) with $0.4 \mathrm{mg} / \mathrm{mL}$ adenine. Culture condition of yeast S.cerevisiae strains were grown at $30^{\circ} \mathrm{C}$.

\section{Equipment}

Equipment used in this study were maceration chamber, evaporator, Petri disk, Erlenmeyer flask, orbit shaker incubator, electrophoresis set (Bio-rad), spectrophotometer UV-vis (Bio-rad), and real-time PCR (Applied Biosystems).

\section{Extraction of Noni Fruit}

Fresh noni fruits were cut into thin slices and dried naturally in the shade. The dried sample $(200 \mathrm{~g})$ was extracted by maceration using $1 \mathrm{~L}$ methanol as a solvent at room temperature for several days occasional shaking and repeated three times with 
methanol to produce macerate. The extract was evaporated using a rotary evaporator to obtain the crude extract for further assay.

\section{Phenotypic Assay}

S.cerevisiae strain cells were streaked on YPDAde media agar with and without 3\% noni fruit extract and incubated at temperature $30{ }^{\circ} \mathrm{C}$ for two days.

\section{Yeast RNA Isolation}

RNA isolation was performed based on manufacturer's protocol. RNA was isolated by the TRIzol (Thermo Fisher Scientific) using Multi-Beads Shocker (MBS) (Yasui Kikai, Japan) and used for quantitative analysis of mRNA content by real-time (RT) PCR. Yeast cells $\left(\mathrm{OD}_{660}=1.0\right)$ grown in 25 $\mathrm{mL}$ YPD liquid medium with or without methanolic extract of M.citrifolia fruit was harvested by centrifugation cell, pellets were optionally chilled in liquid nitrogen and stored in $-80{ }^{\circ} \mathrm{C}$. A $1 \mathrm{~mL}$ of TRIzol and $60 \%$ volume of glass beads. Cells then were disrupted with multi-beads shocker with the following condition: ten cycles of active for 60 seconds and inactive for 60 seconds at $0{ }^{\circ} \mathrm{C}$ at 2,500 rpm. Cells lysis were checked with a microscope (normally $90-100 \%$ lysis occurs). Then, punctuate the bottom of the screw-cap tube with a needle (when punctuate, screw cap should be a little bit opened to decrease pressure). Place this tube into a $2.0-\mathrm{mL}$ microfuge tube, and spin the tubes in the benchtop centrifuge at 3,000 rpm for $1 \mathrm{~min}$ at $4{ }^{\circ} \mathrm{C}$.

After vortexing the collected samples, incubate for $5 \mathrm{~min}$ at room temperature, to permit the complete dissociation of nucleoprotein complexes. Add $0.2 \mathrm{~mL}$ of chloroform per $\mathrm{ml}$ Trizol reagent. Shake tubes vigorously by hand for $15 \mathrm{sec}$ and incubate them at room temperature for $2-3 \mathrm{~min}$. Centrifuge the samples at no more than $12,000 \mathrm{x} \mathrm{g}$ for $15 \mathrm{~min}$ at $4{ }^{\circ} \mathrm{C}$. The following centrifugation, the mixture separates into a lower red, phenol-chloroform phase, an interphase, and colorless upper aqueous phase. RNA remains exclusively in the aqueous phase. The volume of the aqueous phase is about $60 \%$ of the volume of Trizol reagent used for homogenization. Transfer the aqueous phase to a fresh tube, and save the organic phase if isolation of DNA or protein is desired.
Precipitate the RNA from the aqueous phase by mixing with isopropyl alcohol and 3 $\mathrm{M}$ NaoAc. Samples were vortexed and stored at $-20{ }^{\circ} \mathrm{C}$ for at least $30 \mathrm{~min}$ and centrifuge at no more than $12,000 \mathrm{xg}$ for $10 \mathrm{~min}$ at $4{ }^{\circ} \mathrm{C}$. The RNA precipitate, often invisible before centrifugation, forms a gel-like pellet on the side and bottom of the tube. Remove the supernatant and again spin down. Wash the RNA pellet once with $70 \%$ ethanol, adding at least $1 \mathrm{ml}$ of $75 \%$ ethanol per $1 \mathrm{~mL}$ of TRIzol reagent used for the initial homogenization. Mix the sample by vortexing and centrifuging at no more than $12,000 \mathrm{xg}$ for $5 \mathrm{~min}$ at $4{ }^{\circ} \mathrm{C}$. Dry it for $5 \mathrm{~min}$ (not to let the RNA pellet dry completely as this will decrease its solubility) and dissolved in $40 \mu \mathrm{L}$ of sterile water.

\section{Transcriptional Analysis using RT-PCR}

cDNA was synthesized from mRNA using the cDNA Archived kit (Applied Biosystems) according to the Manufacturer's Protocol. Single-stranded cDNA from total RNA was synthesized using $2 \mathrm{X}$ RT master mix on ice consisting of $2.0 \mu \mathrm{L} 10 x \mathrm{RT}$ buffer, $0.8 \mu \mathrm{L} 25 \mathrm{X}$ dNTP Mix (100 mM), $2.0 \mu \mathrm{L}$ $10 \mathrm{X}$ RT Random Primers, $1.0 \mu \mathrm{L}$ MultiScribe ${ }^{\mathrm{TM}}$ Reverse Transcriptase, $1.0 \mu \mathrm{L}$ RNase inhibitor, $3.2 \mu \mathrm{L}$ nuclease-free $\mathrm{H}_{2} \mathrm{O}$. Then, 2X RT master mix were pipetted into each well of a 96-well reaction plate or tube, and $10 \mu \mathrm{L}$ of RNA were added into each well, Samples were put on thermal cycler with the following program to synthesize cDNA, step 1: 10 min on temperature $25^{\circ} \mathrm{C}$, step 2: 120 min on temperature $212{ }^{\circ} \mathrm{C}$, step 3: $5 \mathrm{sec}$ on temperature $85{ }^{\circ} \mathrm{C}$, and step 4: keep on temperature $4{ }^{\circ} \mathrm{C}$. The resulted cDNA was used as the template for quantitative real-time PCR with real time-PCR system using following primer pairs (Sigma-Aldrich, Co. Japan) and SYBR Green RT-PCR Reagents kit (Applied Biosystems).

The primer pairs used in this experiment designed were presented in Table 1. The thermal cycling condition included 2 min at $50{ }^{\circ} \mathrm{C}$ and $10 \mathrm{~min}$ at $95{ }^{\circ} \mathrm{C}$. 7 Serial 5 fold dilutions (ACT1 cDNA $1000 \mathrm{ng} / 40 \mu \mathrm{L}$, $200 \mathrm{ng} / 40 \mu \mathrm{L}, 40 \mathrm{ng} / 40 \mu \mathrm{L}, 8 \mathrm{ng} / 40 \mu \mathrm{L}, 1.6$ $\mathrm{ng} / 40 \mu \mathrm{L}, 0.32 \mathrm{ng} / 40 \mu \mathrm{L}$, and $0.064 \mathrm{ng} / 40 \mu \mathrm{L}$ used in this experiment to generate a standard curve. Thermal cycling proceeded with 40 cycles of $95{ }^{\circ} \mathrm{C}$ for $0.5 \mathrm{~min}$ and $60{ }^{\circ} \mathrm{C}$ for 2 min (Gibson, Heid, \& William, 1996). 
Table 1. Primer used in this experiment

\begin{tabular}{|c|c|c|c|}
\hline No & Primer & Nucleotide Sequences & Sequence (bp) \\
\hline \multirow[t]{2}{*}{1} & KfRT-ACTI & 5'- TGGTATGTGTAAAGCCGGTTTTG -3' & (23) \\
\hline & KrRT-ACT1 & 5'- CATGATACCTTGGTGTCTTGGTCTA -3' & (25) \\
\hline \multirow[t]{2}{*}{2} & KfRT-YOXI & 5'-CGATGATCGCGGAACCA-3' & (17) \\
\hline & KrRT-YOXI & 5'- GGCGCTTTCCACAGATCTTG-3' & $(20)$ \\
\hline \multirow[t]{2}{*}{3} & KfRT-YHPI & 5'- TCCACAGGCTGTGGATTTCTTA-3' & $(22)$ \\
\hline & KrRT-YHPl & 5'- CCAGCTTCTTGGGCTTGGATAA-3' & $(22)$ \\
\hline \multirow[t]{2}{*}{4} & KfRT-TAH11 & 5'- CAGCCTCACCAACAGGCTTT-3' & $(20)$ \\
\hline & KrRT-TAH11 & 5'-GTAGGCAGCATTCTGTTCAGCAT-3' & (23) \\
\hline \multirow[t]{2}{*}{5} & KfRT-SICl & 5'-CAAGAAAGTGAAGACGAGGAAGACA-3' & $(25)$ \\
\hline & KrRT-SICl & 5'- TCATCTGATGCAAAGGGATTTTT-3' & (23) \\
\hline \multirow[t]{2}{*}{6} & KfRT-MCMI & 5'- CCTCACCAACAGGCTTTTGC-3' & $(20)$ \\
\hline & KrRT-MCM1 & 5'-GTAGGCAGCATTCTGTTCAGCAT-3' & (23) \\
\hline \multirow[t]{2}{*}{7} & KfRT-MBPl & 5'- TCAATGGCCACGTCCGTAT-3' & (19) \\
\hline & KrRT-MBPl & 5'- ATGGATTACTATCGGCAAAATCG-3' & (23) \\
\hline \multirow[t]{2}{*}{8} & KfRT-FUS3 & 5'- GTGGCCACACGTTGGTACAG-3' & $(20)$ \\
\hline & KrRT-FUS3 & 5'-CGTCCATGGCCCTTGAGTAT-3' & $(20)$ \\
\hline \multirow[t]{2}{*}{9} & KfRT-FARI & 5'-GGAAGAGATGGATCCGGTGTAG-3' & $(22)$ \\
\hline & KrRT-FARI & 5’- TTGTCCATCCGTCCCAATTT-3' & $(20)$ \\
\hline \multirow[t]{2}{*}{10} & KfRT-DBF4 & 5'- GCTGTCCAAGTCAGCAAAGGT-3' & (21) \\
\hline & KrRT-DBF4 & 5'- TGCCATTCCAGCAATTCC-3' & $(18)$ \\
\hline \multirow[t]{2}{*}{11} & KfRT-CDC20 & 5'- GGAGCTTCGCAAAACAAGGT -3' & (20) \\
\hline & KrRT-CDC2O & 5'- TGGCGACGCGTTTGG -3' & $(15)$ \\
\hline \multirow[t]{2}{*}{12} & KfRT-CDC7 & 5'- CAAACACCTCCTATGGTCACCAT-3' & $(23)$ \\
\hline & KrRT-CDC7 & 5'- CAGATCCACCCCATTTACATTGT-3' & (23) \\
\hline \multirow[t]{2}{*}{13} & KfRT-CDC6 & 5'- TCTGAACACAGGTCCGATTCAC-3 & $(22)$ \\
\hline & KrRT-CDC6 & 5'- CATATCAAGCTGGGCAGTCTTG-3 & $(22)$ \\
\hline \multirow[t]{2}{*}{14} & KfRT-WHI5 & 5'- GGCCCATCCGCGAAAT-3' & (16) \\
\hline & KrRT-WHI5 & 5'- TGCAGCTTGACTAACGCGTAA-3' & (21) \\
\hline \multirow[t]{2}{*}{15} & KfRT-SWI6 & 5'- TGAAGGCGATATTTCCAAACTATTAG-3' & (26) \\
\hline & KrRT-SWI6 & 5'- CTGCGGGAAGTTGATTTCGT-3' & $(20)$ \\
\hline
\end{tabular}

\section{RESULTS AND DISCUSSION}

Noni fruit has been reported to have broad therapeutic effects. However, the mechanism for this effect remains unclear (Krishnaiah, Nithyanandam, and Sarbatly, 2012). In this study, noni fruit was extracted using methanol as a solvent. Some studies involved the methanolic extract of noni fruit, which showed antimicrobial, antioxidant, pesticidal, anti-HIV, anti-leishmaniasis, and hypotensive activities (Siddiqui et al., 2007).

The present study is to utilize yeast S.cerevisiae as a model organism to identify an anticancer medicinal plants candidates with anti-proliferative properties. Identification of antiproliferative properties for anticancer plant candidates can be used S.cerevisiae as a model. The growth of S.cerevisiae was inhibited their proliferation by $3 \%(\mathrm{w} / \mathrm{v})$ noni fruit extract (Figure 1). Treatments with 3\% (w/v) noni fruit extract have inhibited proliferation of S.cerevisiae. Both of S.cerevisiae strains FY833 and BY4741 showed growth on YPDAde agar medium in the absence of noni fruit extract where yeast colonies grew well after one-day incubation at $30{ }^{\circ} \mathrm{C}$. The inhibited growth of cell can be observed through sensitive growth phenotypic. Some gene expression changes lead to the sensitive growth phenotypic of S.cerevisiae on the medium (Hermansyah, et al., 2009). 


\section{a) YPD}

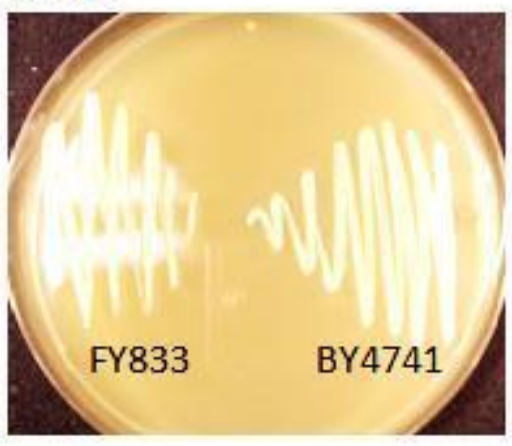

a) YPD + 3\% Extract M.citrifolia

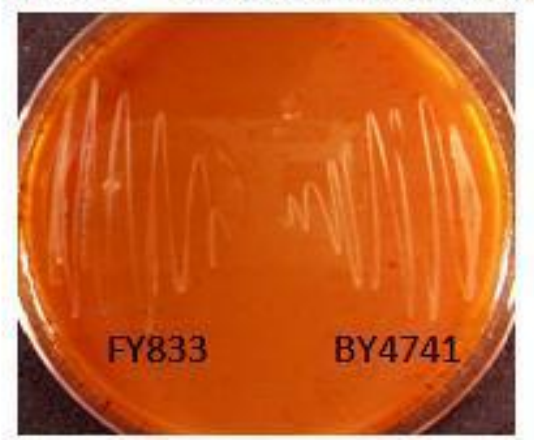

Figure 1. The phenotypic sensitive growth of S.cerevisiae in the presence of $3 \%$ noni fruit extract (a) and without extract (b). Phenotypic growth was observed after incubated at $30{ }^{\circ} \mathrm{C}$ for $24-48$ hours

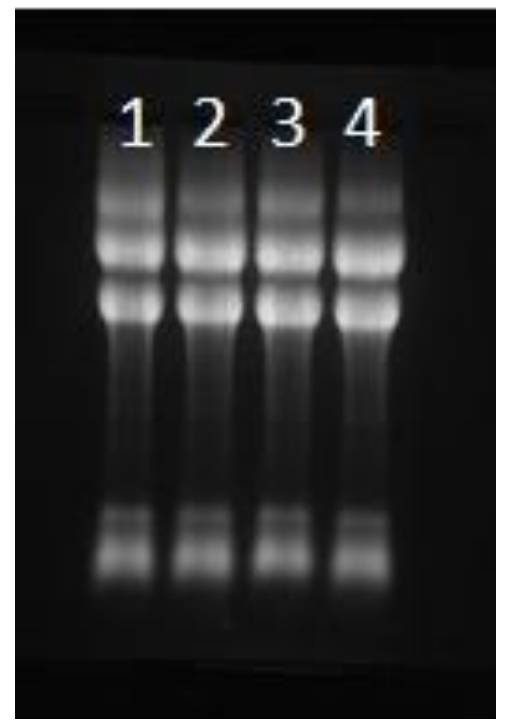

Figure 2. Electrogram showing RNA samples. RNA isolated from cells cultures without noni fruit extract (1 and 2) and with $1 \%(\mathrm{w} / \mathrm{v})$ noni fruit extract. Yeast cells $\left(\mathrm{OD}_{660}=1.0\right)$ grown in $25 \mathrm{~mL}$ YPD liquid medium with or without noni fruit extract. RNA was isolated by the TRIzol method using Multi-Beads Shocker (MBS). Finally, RNA samples were dissolved in $40 \mathrm{uL}$ of sterile water.
Prior to analyzing the gene expression level changes, RNA samples were isolated from the cells cultured in YPDAde treated with $1 \%(\mathrm{w} / \mathrm{v})$ noni fruit extract, and in YPDAde without noni fruit extract as a positive control. RNA samples were isolated using TRIzol method successfully as shown on RNA agarose electrophoresis data (Figure 2). RNA samples were then converted into cDNA.

Some genes such as SWI6, CDC6, CDC7, WHI5, CDC20, YOX1, YHP1, TAH11, SIC1, MCM1, MBP1, FUS3, FAR1, and DBF4 involved in cell cycle regulation in S.cerevisiae (Rubinstein, Hazan, Chor, Pinter, \& Kassir, 2013; http://www.yeastgenome.org). In this analysis, the $A C T 1$ gene was commonly used as reference gene. Those genes were quantita-tively measured their gene expression level. Gene expression changes were observed between FY833 strain cells cultured in the presence of $1 \%(\mathrm{w} / \mathrm{v})$ noni extract compared with FY833 strain cells in the absence of $1 \%(\mathrm{w} / \mathrm{v})$ noni fruit extract. Further observation, we comparing gene expression changes between strain FY833 and BY4741 cells in the presence of $1 \%$ noni fruit extract.

The results showed that gene expression level of WHI5, CDC6, CDC20, YOX1, YHP1, SIC1, FUS3, and FAR3 increased, while gene expression of TAHI1, $M C M 1$, and $D B F 4$ decreased (Figure 3). The level of each gene SWI6, CDC7, and MBPI were similar level in both conditions either with or without noni fruit extract treatment. Further observation, in the presence of $1 \%$ $(w / v)$ noni fruit extract, the expression level of those genes differed between in S.cerevisiae strain FY833 and BY4741. It observed that in strain FY833, level of each gene SWI6, CDC7, CDC20, YOX1, YHP1, TAH11, SIC1, MCM1, FUS3, FAR1, and $D B F 4$ were higher than in the strain BY4741. The expressions level of genes MBP1, WHI5, 
and $C D C 6$ were almost same in both strains (Fig. 3). CDC6 is an essential regulator of DNA replication protein that also participates in the activation and maintenance of checkpoints and in some cases affects gene expression (Casmiro, Crosariol, Loro, Li, \& Pestell, 2013).
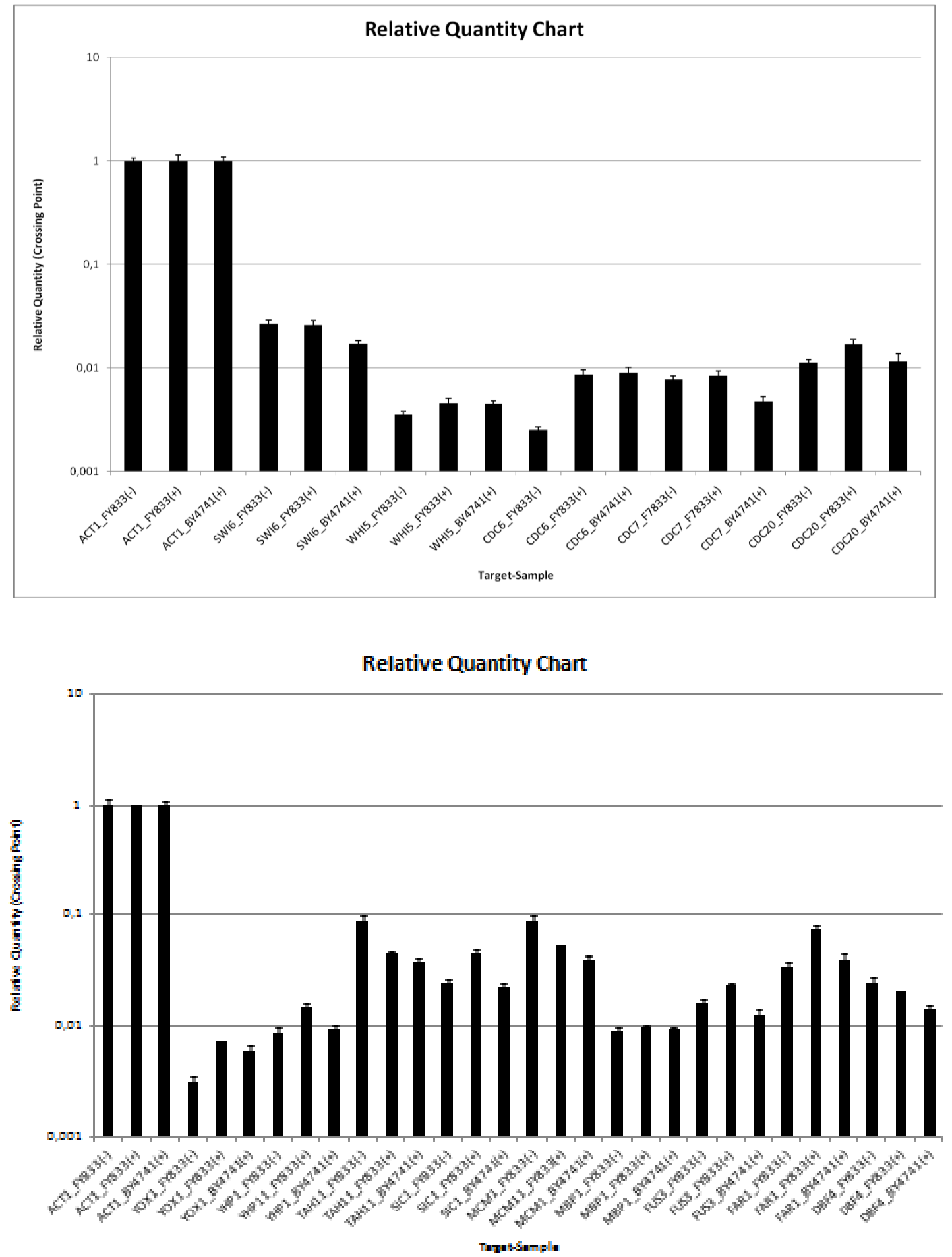

Figure 3. Transcriptional analysis using RT-PCR. Strand cDNA was synthesized using a high capacity cDNA Archived kit (Applied Biosystems). The resulted cDNA was used as the template for quantitative real-time PCR with real-time PCR system (Applied Biosystems) using following primer pairs (Sigma-Aldrich, Co. Japan). Thermal cycling proceeded with 40 cycles of $95{ }^{\circ} \mathrm{C}$ for $0.5 \mathrm{~min}$ and $60{ }^{\circ} \mathrm{C}$ for $2 \mathrm{~min}$. The samples were carried out in triplicate. 
Its function is the assembly of prereplicative complexes at origins of replication during the G1 phase of the cell division cycle, activation and maintenance of the checkpoint mechanism that coordinate $\mathrm{S}$ phase and mitosis, and recent studies have unveiled its proto-oncogenic activity (Borlado and Mendez, 2007). In the presence of $1 \%$ noni fruit extract, among those changed gene expressions, CDC6 or cell division cycle-6 was the highest expression changes, more than two folds. Overexpression of genes could explain the function of genes. Overexpressed human $C D C 6$ gene may suffer the nuclearcytosolic translocation (Alexandrow \& Hamlin, 2004).

Overexpression of WHI5 in swi64 mutant inhibits cell growth on plates (Adames et al., 2015). Overexpression of CDC20 overrides the G2/M-phase arrest caused by DNA damage, allowing cells to undergo anaphase and to enter the subsequent division cycle (Lim, Goh, \& Surana, 1998). Transcriptional level of genes increased, oppositely genes expression of decreased, while the expression level of genes relatively unchanged.

\section{CONCLUSION}

The noni fruit extract inhibited growth S.cerevisiae strain FY833 and BY4741 showed by the gene expression which is expression level of CDC6, CDC20, FAR1, FUS3, SIC1, WHI5, YOXI, and YHPI increased while DBF4, MCM1, and TAHI1 decreased. However, noni fruit extract did not change the expression level of genes $C D C 7$, MBP1 and SWI6. Gene expression changes might associate with anti-proliferative effect from noni fruit extract.

\section{ACKNOWLEDGEMENT}

This work was supported by Fundamental Research grant Directorate General Higher Education 2016.

\section{REFERENCES}

Adames N.R., Schuk P.L., Chen, K.T., Murali, T.M., Tyson, J.J., \& Peccoud, J. (2015). Experimental testing of a new integrated model of the budding yeast START transition. Molecular Biology of the Cell, 26 (22), 3966-3984.

Akihisa, T., Matsumoto, K., Tokuda, H.,
Yasukawa, K., Seino, K., Nakamoto, K., Kuninaga, H., Suzuki, T., \& Kimura, Y. (2007). Anti-inflammatory and potential cancer chemopreventive constituents of the fruits of Morinda citrifolia (Noni). Journal of Natural Product, 70, 754-757.

Alexandrow, M.G., \& Hamlin, J.L (2004). Cdc6 chromatin affinity is unaffected by Serine-54 phosphorylation, S-phase progression, and overexpression of cyclin A. Molecular Cellular Biology, 24(4), 1614-1627.

Borlando, L.R., \& Mendez, J. (2008). CDC6; from DNA replication to cell cycle checkpoints oncogenesis. Carcinogenesis, 29(2), 237-43.

Calvert, M.E. \& Lannigan, J. (2010). Yeast cell cycle analysis: combining DNA staining with cell and nuclear morphology. Current Protocols in Cytometry, 9(32), 1-6.

Calvert, M.E., Lanniga, J.A., \& Pemberton, L.F. (2008). Optimization of yeast cell cycle analysis and morphological characterization by multispectral imaging flow cytometry. Cytometry, 73(9), 825-33.

Casimiro, M.C., Crosariol, M., Loro, E., Li, Z., \& Pestell. R.G. (2013). Cyclins and cell cycle control in cancer and disease. Genes \& Cancer, 3(11-12), 649-657

Chan-Blanco, Y., Vaillant, F., Perez, A.M., \& Brat, P. (2006). The noni fruit (Morinda citrifolia L.) : A review of agricultural research, nutritional and therapeutic properties. Journal of Food Composition Analysis, 19, 645-654.

Furusawa, E., Hirazumi, A., Story, S., \& Jensen, J. (2003). Morinda citrifolia (Noni) on sarcoma 180 ascites tumor in mice. Phytotherapy Research, 17(10), 1158-64.

Gibson, U.E., Heid, C.A., \& William, P.M. (1996). A novel method for real-time quantitative RT-PCR. Genome Research, 6(10), 995-1001.

Hermansyah, Sugiyama, M., Kaneko, Y., \& Harashima, S. (2009). Yeast protein phosphatase Ptp2p and Msg5p are involved in G1-S transition, CLN2 transcription, and vacuole morphogenesis. Archive of Microbiology, 191, 721-733.

Krishnaiah, D, Nithyanandam, R., \& Sarbatly, R. (2012). Phytochemical constituents 
and activities of Morinda citrifolia L., Phytochemicals-A Global perspective of their role in nutrition and health, Croatia : InTech

Lim, H.H., Goh, P.Y., \& Surana, U. (1998). $\mathrm{Cdc} 20$ is essential for the cyclosomemediated proteolysis of both Pds1 and $\mathrm{Clb} 2$ during $\mathrm{M}$ phase in budding yeast. Current Biology, 8(4), 231-237.

Potterat, O., \& Hamburger, M. (2007). Morinda citrifolia (Noni) fruitphytochemistry, pharmacology, safety. Planta Medica, 73(3), 191-199.

Rubinstein A., Hazan, O., Chor, B., Pinter R.Y., \& Kassir, Y. (2013). The effective application of a discrete transition model to explore cell-cycle regulation in yeast. BMC Research Notes, 6(311), 1-13

Siddiqui, B.S., Sattar, F.A., Ahmad, F., \& Begum, S. (2007). Isolation and structure elucidation of chemical constituents from the fruit of Morinda citrifolia Linn. Archives of Pharmacal Research, 30(8), 919-23

Takashima, J., Ikeda, Y., Komiyama, K., Hayashi, M., Kishida, A., \& Ohsaki, A. (2007). New constituents from the leaves of Morinda citrifolia. Chemical and Pharmaceutical Bulletin, 55(20), 343-5.

Wang, M.Y., West, B.J., Jensen, C.J., Nowicki, D., Su, C., Palu, A.K., \& Anderson, G. (2002). Morinda citrifolia (Noni) : a literature review and recent advances in Noni research. Acta Pharmacologika Sin, 23(12), 1127-41.

Winston F., Dollard C., \& Ricupero-Hovasse, S.L. (1995). Construction of a set of convenient Saccharomyces cerevisiae strains that are isogenic to S288C. Yeast 11, 53-55. 